\title{
The Impact of Crime among Learners in High School
}

\author{
T. Pitso a \\ T. P. Njeje $b$ \\ T. D. Bonase ${ }^{b}$ \\ T. Mfula $b$ \\ B. S. Nobendle $b$ \\ P. Nogaga $b$ \\ a Department of Psychology, University of Fort Hare, P. Bag X1314, Alice 5700, RSA \\ Email: tsoloz2002@yahoo.co.uk \\ ${ }^{b}$ Department of Social Work, University of Fort Hare, P. Bag X1314, Alice 5700, RSA
}

Doi:10.5901/ajis.2014.v3n1p333

\begin{abstract}
The issue of crime committed at school is escalating among high school learners and this is a serious issue in South Africa as it has turned to be contagious to the neigbouring schools. The qualitative study assessed the impact of crime among high school learners, their parents and teachers as well. The open-ended questionnaires were distributed to 38 learners in two high schools in Alice, Eastern Cape, 19 learners from each school. Simple random sampling was used to select respondents. Sub-topics of questionnaires were divided in to three sections: biographical information, the causes of crime among learners, and the impact of crime in schools. The data was analysed using content analysis. The results of this study indicated that this crime may be caused mainly by poor role modelling at home by parents/ guardians, by significant others such as the teachers and the older students through negative peer pressure. The impact of this crime may lead to victims dropping out of school due to fear of victimization by their fellow students and imprisonment by the perpetrators. Teachers are also affected by the crime in a way that they live with fear and insecure inside school premises because other learners carry dangerous weapons inside the school premises. Findings showed that crime does affect the learner's in their studies and psychological; in a sense that crime scene always leaves post-traumatic stress disorders to the observers. It also promotes retaliation behaviour among the learners and they spent less time concentrating on their books.
\end{abstract}

Keywords: Crime, Impact, Learners, Causes, School

\section{Background of Crime}

Cloete and Stevens (2004) define crime as an unlawful act or omission which is either a prohibition or behaviour which is punishable by authorities. While according to Snyman (Cf. 2002) crime is unlawful, blameworthy conduct punishable by law.

The Bill of Rights, Sections 12 and 24, states clearly that everyone has the right to be free of all forms of violence in a safe environment. This right needs to be protected and universally recognized, and it implies that every learner has a constitutional right to learn in a safe environment, so that those who want to study can do so without disruption. Stewart (2004) says that schools are required to implement management systems to protect learners from harm, including incidents of bullying. Prinsloo (2005) posited that schools have to create an environment conducive to learning, and to ensure the safety of learners and educators. Failing to make schools safe and compatible for learners, without fear of harassment and bullying, could result in serious discipline problems.

De Wet (2003) examined the perceptions and experiences of crime regarding safety at their schools, and from the learners' responses in the Eastern Cape it was found that the environment in which the schools were located constituted a problem regarding safety. Some potential problem areas were identified, namely the school grounds, empty 
classrooms, parking areas, and learner bathrooms

\subsection{Crime in schools}

School crime is defined by Zulu, Urrbani, \& Van der Merwe. (2004), as any behaviour of learners, educators, administrators or non-school persons, attempting to inflict injury on another person or to damage school property. Internationally, violence both affects schools and is perpetuated and perpetrated by schools (e.g. Harber 2004; Pinheiro 2006; PLAN 2008; Smith \& Vaux 2003). Crime in schools can come from different sources, take on many forms and involve different actors. For example, bullying may be learned outside the school but perpetuated inside the school because the school ignores it or doesn't deal with it satisfactorily. It may also involve different actors at different times inside the school - for example, learners may bully each other, teachers may bully learners, learners may bully teachers, parents may bully teachers, and principals may bully teachers or be bullied by them. School violence also takes place in different ways and in a wide range of contexts

School crime is a problem of particular significance in South Africa. Shootings, stabbings, and physical and emotional violence have taken place in both public and private schools (Akiba, LeTendre, Baker \& Goesling 2002; Zulu, Urbani \& Van der Merwe 2004). A report by the South African Institute of Race Relations (SAIRR) (2008); suggested that only $23 \%$ of South African learners said they felt safe at school. The release of the crime statistics for the financial year 2006/2007, aroused much public interest and concern, perhaps intensified by the prevalent increase in the murder and aggravated robbery rates. There were some reported decreases, such as attempted murder (3\%), rape (5.2\%) and indecent assault (5.5\%). There is an urgent and sustained need for an explanation of crime trends and consistent monitoring of this phenomenon.

The crime statistics for 2006/2007 (SAPS 2007) did not clearly indicate whether South Africa was winning or losing the battle to reduce crime as the figures tended to fluctuate.

Burton and Leoschut (2013) stated the different provincial trend emerges when property-related crimes are included in the analysis. Mpumalanga (71.8\%) emerges as the province where criminal victimization is highest in schools, followed by the Free State (62\%) and the Eastern Cape (60.8\%). This statistics shows that there is high rate of crime in Eastern Cape schools, where the study is going to be conducted. According to Statistics South Africa (2012) the types of crimes that are mostly found are house-breaking, burglary, rape and assault, bullying, robbery and sexual harassment. House-breaking and burglary calls for $38.3 \%$, robbery $71 \%$, sexual offence $44 \%$ (of the reported cases).

\section{Factors that Influence Learners to Commit Crime}

According to UN-HABITAT (2007), several factors influence the incidence of crime and violence. These include family, parenting styles, social, peer, drug alcohol abuse and economic factors that produce opportunities and incentives for criminal behaviour and violent acts, as well as the situations that frame victimization. All these factors are discussed in details below;

\subsection{Family factors}

According to Broadhurst; Duffin, and Taylor, (2008), the dysfunctional family, among family factors, has been mentioned as playing an important role in shaping the behaviour of learners towards criminality. He also explained further that a dysfunctional family is defined by a marital disruption such as divorce, separation and unwedded or single parenthood. Utting; Montiero, \& Ghate, (2006), extended that although the family may seem intact, it might be characterized by spousal violence, child abuse and alcoholism, which can later result on child's criminality. In addition, divorce and separation have been identified as causing stress for the whole family (Young; Fitzgerald; Hallsworth, \& Joseph, 2007). Learners who are part of this situation feel frustrated and often display behavioural problems. These behavioural problems can be seen through anger, disruptive behaviour and aggression and the combination of these leads to criminal behaviour (Young et al, 2007).

These factors are also seen in learners who live in a single parent family. Although the absence of one parent is not in itself an indication that parental support may be lacking, some hold the view that a shortage of positive male role models for young boys increases the likelihood of crime (House of Commons, 2007).

In many cases, young people who take part in group-based offending may have lived in households where family members are involved in criminal activity. Through family involvement, the idea of crime becomes normalized (Utting et 
al, 2006).

\subsection{Parenting styles}

According to Kopko, (2007) permissive parents are indulgent and passive in their parenting, and believe that the way to demonstrate their love is to give in to their adolescent learners' wishes. In essence they say statements like these, "sure, you can stay up late if you want to," and "you do not need to do any chores if you don't feel like it." Permissive parents do not like to say no or disappoint these learners (Utti, 2006). Parents do not view themselves as active participants in shaping their learners actions instead they view themselves as a resource, should the adolescent choose to seek their advice (Inman, Howard, Beaumont \& Walker, 2007). In accordance with the above view such learners are more likely to be so demanding to their parents, as he or she may want an expensive smart phone and his or her parents may not have that kind of money to buy a phone, it may be easy for learners to steal the phone from the other learner at school and for that matter no one will ask the child where he or she gets the phone as the parent may fear to disappoint the child.

\subsubsection{Uninvolved parenting}

According to Wargo (2007) uninvolved Parents do not have nurturance and do not respond to the needs of their children. They minimize their interaction time and, in some cases, are uninvolved to the point of being neglectful. Uninvolved parents are indifferent to their adolescent leaner's needs, whereabouts, or experiences at school or with peers. These parents may be overwhelmed by their circumstances or they may be self-centered. Parents might also engage in this style if they are tired, frustrated, or have simply "given up" in trying to maintain parental authority (Steinberg, 2001). If children fail to form a secure attachment to an adult carer, this will affect their social and emotional development. Disorganized attachment most commonly occurs in cases of abuse, neglect or abrupt separation, and can be caused by parental mental health problems or alcohol and drug use (Home Office, 2003)

According to Juvenile Justice Bulletin (2000), a lack of parental interaction and involvement with children may increase children's future risk for crime. Similarly, (Boroffice 2004) found that learners whose parents did not engage in leisure activities with them more often exhibited violent behavior as teenagers and is more likely to be involved in criminal activities at school. In addition, Hill and Hill (1994) stated that poor parent involvement in the school and lack of the parental supervision and training are all links in the chain, which leads a learner into crime. In essence those parents do not even attend school meetings and visit school to get feedback about their children's academic performance, such children can easily lead to truancy because their parents does not even care about their presence at school.

\subsection{Social factors}

Instability within the community also shapes the behaviour of the learners. Community is a group of people who live in the same area or who have the same interests, religion, or nationality (Leoschut, 2008). Instability means lack of stability (Schwartz \& Hopmeyer Gorman, 2003).

The instability of a community can be traced to political violence, social violence, suicides and crimes such as hijacking, kidnapping, rape, hostage, house breaking, senseless killing, gangsterism, et cetera. Such a community or environment may place learners in a stressful situation and compel them to be aggressive. Learners may experience psychological problems in adjusting to normality and end up believing that violence is the only way to address problems. Because of these incidents learners lose respect for authority and reject restraint or discipline (Ward, 2007).

\subsection{Peer influence}

Peer interaction or peer pressure has been highlighted, among other factors that cause learners to commit crime, as most crucial in shaping the behaviour of the learners. Peer pressure is defined as compulsion to do or obtain the same things as others in one's peer group (Young et al, 2007). Several studies have found a consistent relationship between involvement in a criminal peer group and criminal behavior NCH (2008). Noted that for youth ages 12-14, a key predictor variable for delinquency is the presence of criminal peers. Peer pressure is an age- old plaque that predominantly affects young people and be quite an influencing factor in committing crime. Some learners are only a long for the ride. Peer pressure guide other teens into situation in which they feel there is no way out. There are others who became enmeshed in a crime because they are simply at a wrong a place at the wrong time (Chalmers, 2009). Research indicates that 
where learners are strongly attached to their peers, spend long periods of time with peers and there are extensive patterns of misbehavior has a strong, positive effect on their own misbehavior (Smith and Bradshaw, 2005). .Aggressive and antisocial learners begin to affiliate with one another in childhood, and this pattern of aggressive friendships continues through adolescence (Kupersmidt, Coie, and Howell, 2003).

According to McCord and colleagues (2001), Factors such as peer delinquent behavior, peer approval of delinquent behavior, attachment or allegiance to peers, time spent with peers, and peer pressure for deviance have all been associated with adolescent criminal behavior. Turner et al (2006), points out that peer influence is a major factor in the decisions made by young people to join groups or to offend. In addition (Young et al, 2007), many young people in offending groups feel a profound need to develop secure relationships with peers. For this reason, in much of the research conducted, young people spoke of the desire to impress and to gain the respect of friends, and in some cases, this can serve as a catalyst for offending behaviour and the acquisition of weapons $(\mathrm{NCH}, 2008)$.

\subsection{Economic factors}

According to Young et al, (2007) economic deprivation affects young people in several ways and these can have a direct or indirect impact on peer relationships and offending. For example, young people who experience poverty are more likely to live in deprived areas and in poor quality housing. In these areas, crime levels and the fear of victimization are high, and young people may seek to protect themselves by carrying weapons or forming groups. In addition, there may be greater exposure to anti-social attitudes and behaviours which means that young people are more likely to offend, as crime has become normalised (Campbell, 2000).

Young people who grow up in deprived communities have limited opportunities to achieve educational and economic success (Duffy, \& Gillig, S eds, 2004). This is coupled with increased opportunities to become involved in crime. For this reason, young people sometimes engage in criminal activity to fulfil their aspirations for material wealth and social status where this is not available through legitimate routes (Margo, 2008).

\subsection{Drug abuse}

Alcohol leads to higher levels of offending and high-risk behaviours (HM Government, 2007).

Young people who drink alcohol at least once a month are responsible for a disproportionate amount of crime in the 10 to 17 age group (Matthews; Brasnett, and Smith, 2006). Drinking on a regular basis is likely to have an adverse effect on school attendance and performance and may increase the likelihood of permanent exclusion (HM Government, 2007), which in turn increases other risk factors. Recent studies reveal that young drinkers are also more likely to admit to being involved in violent incidents (Richardson, and Budd, 2003).

Utting et al (2006) suggest that drugs are more easily available in deprived, urban areas due to the presence of adult criminal structures involved in the supply chain, and that this may have an impact on the level of offending by young people in these communities.

\section{Impact of Crime among Learners in High School}

The study found out that the impact of crime amongst learners at high school is negative. Crime is a serious problem, it negatively affect the learners school performance. Learners who are involved in crime are likely to perform badly at school. According to Thoaele (2003) revealed that young people who have whose association was based on substance use has also indulged in criminal involvement particularly, property crimes. Drug abuse and even alcohol use directly contribute to violent crimes if taken in excess, especially if taken in a group context where there is a strong pressure to conform to the group's rules.

The South African Human Rights Commission (2007) has found that $40 \%$ of children who interviewed said they had been the victims of crime at school. More than a fifth of sexual assaults on South African children were found to have taken place in school. Exposures to domestic violence, gangsterism and drugs have had a substantial impact on students. The families who use alcohol and drugs influence the learners to be the users as well; children learn behaviours from their parents and other family members.

In addition, crime impacted negatively on the schooling experience, resulting in difficulties concentrating at school, absenteeism and poor school performance. When we were conducting research some few learners reported not feeling any negative feelings following their experiences of crime at school. 
Another form of crime that can reflect the wider society and exist in schools relates to racial or ethnic discrimination, i.e. hostility towards the "other" based on skin colour or cultural differences. There is no doubt that the wider apartheid political system and resistance to it impacted on schools in a violent way in the 1970s and 1980.

Parents and teachers may also feel overwhelmed by situations that they perceive as out of their control and beyond their influence,( Bowen \& Chapman, 1996). Many of the teens who experience the highest levels of danger are likely to face other distressing conditions, (for example, economic distress and potential abuse and neglect by their family system) that increase their risk for poor psychosocial adjustment and school failure,(Garbarino et al.,1992). One mechanism by which crime or aggressive behaviour among learners affects academic performance is directly impeding teaching and learning process in the classroom, (Lochman, Lampron and Harris, 1998). In addition, learners who are physically and verbally aggressive in the classroom have a negative impact on the education of their classmates by directing their teachers from teaching and reducing the amount of time students are engaged in learning.

More than one out of ten students (11\%) said that crime or the threat of crime has caused them to stay home from school or cut class,(Harris \& Associates, Incorporate, 1995).Criminal acts on learners create so much anger that victimized learners sometimes later commit aggressive acts against others (Bartollas,1993). In addition crime has a negative impact on the emotional development of the learner. This leads to truancy and disruptive behaviour in school, and generates so much pain that alcohol and drugs are viewed by the victimized learner as a needed means of escape. According to Thanyani, 2003, stress is experienced when a learner subjectively responds to a criminal situation or event. Stressors which are perceived to be specially threatening create a fear response that leads to sickness, anger and absenteeism from school and decreased levels of a learner's performance.

Learners are exposed to situations, For example, gun violence in which they are victims, turn out to be an extremely traumatic affair (Bezuidenhout \& Joubert, 2003) The experience of trauma results in the learner being too stressed to cope with learning. Galas, 1997, say, learners who due to crime in school, are stressed out, in pain and struggling for survival, drug abuse may be a solution.

Drug taking is also a criminal related activity (Click, 1995). Though learning has strong cognitive components, it presupposes a stable affective base. This implies that a learner who is emotionally disturbed or upset may experience problems with effective learning and scholastic achievement, as may be the case with the learner who is affected with crime (Gopie, 2003).

\section{Conclusion}

The study found out and outlined the types of crimes that are mostly committed in school. Among those crimes, bulling has been seen is the one of them. These kinds of crimes put other learners and even teachers at risk. The writers took a look on the causes of these crimes in school. It has been noted that they don't begin at school, but it is just where they are manifested, there are several factors that influence learners to commit crime as mentioned above. As we know that family is a primary socialization of a child, and there is that saying "charity begins at home" these affect the child's behaviour mostly. Dysfunctional families like single parent families, families with divorced parents can lead to the criminality of a child because there is a lack of parental guidance, especially in boys where there is no father. Children can also develop criminal behaviour when they associate themselves with peers that are criminals. Economic factors has been seen also as causing criminality among learners, because some learners commit crime to earn money to support themselves or even their families, in those families where here is no member of the family working. The most influential factor that has been discovered by many writers is substance abuse because when one is under the influence of substances does not care what will happen after has committed crime.

Crime committed by learners has an impact among learners, teachers and parents. Learners that are bullied by others at school, end up avoiding school, staying in their homes during the time of school because they are afraid of the offenders. Others do not perform well at school because of the trauma caused by the offenders. Also teachers are scared in school environment because other learners bring deadly weapons inside school premises. In parents, crime by learners affects them mostly psychologically, because they develop stress because of their children's unlawful acts.

\section{Recommendation}

The study has used a variety of research methods and found different types of crime related in schools especially in South African provinces. Some types of crime affecting learners in schools, for example use of illegal drugs, consumption of alcohol, and dangerous weapons which facilitate violence. The impact of crime negatively affects the learners school 
performance, whose association is based on substance abuse has also indulged in criminal involvement.

The study has explained that families who use alcohol and drugs also have an influence to the learners to be users as well that resulted the learners to engage in criminal activities. In the study it is also highlighted that some few learners reported not feeling any negative feelings following their experiences of crime at school. From this study it is clear that the teachers, learners, families and communities are affected by the crime in schools. More than one out of ten students said that crime has caused them to stay home from school.

In this study the causes of the crime have been explained, that needs to be considered as a major problem, for example, dysfunctional family, peer pressure, poverty, parental-lack of discipline and parent-child relationship. The trauma that experience by the learners resulted to stress. Some learners resulted to take short cuts by committing suicide due to the lack of support from the family system. The study has explained that the wider apartheid political system and resistance to it impacted on schools in the 1970s and 1980. Crime has a negative influence on the morale of both educators and learners, as well as the culture of teaching and learning. Each educator and learner has the right to work and play in a secure and safe school environment and neighborhood. Therefore it is important to do everything possible to eliminate crime in schools and neighborhood. Schools need to create a space where educators can teach and learners can learn. Teaching and learning require a safe and tolerant learning environment.

\section{References}

Akiba, M, LeTendre, GK, Baker DP \& Goesling, B. (2002). Student victimisation: National and School System Effects on School Violence in 37 Nations. American Educational Research Journal. Vol. 39, No. 4 (Winter 2002), pp. 829-853.

Bezuidenhant and Jourbert, (2003). Child and youth misbehavior in South Africa: A holistic view. Pretoria: Van Schaik Publishers.

Boroffice, O. B. (2003) Recreation and Health Behaviour of Adolescents. In Contemporary Issues and Researches on Adolescents (Edited by I. A. Nwanuoke, O. Bampgbose \& O. A. Moronkola). Ibadan (Omoade Printing Press)

Bowen, G.L, and Chapain, M.V. (1996). Poverty, neighborhood danger, social support, and the individual adaptation among at risk youth in urban areas. Journal of Family Issues,17,641-666.

Broadhurst, K; Duffin, M and Taylor, E (2008) Gangs and schools: Interim report: An interim report for the NASUW.T London: NASUWT The teaching union.

Ciek, L . (1995). Criminology. Boston: Allyn and Bacon.

De Wet, C. (2003). Eastern Cape Educators' perceptions of the ca uses and the scope

of school violence. Acta Criminologica, 16(3), pp. 89-106.

Duffy, M \& Gillig, S eds (2004) Teen gangs: A global view. London: Greenwood Press.

Galas, J. (1997). Drugs and sports. New York: Lucent Books

Garbarino, J., Dubrow, N.,Kosteny, K., and Pardo, C. (1992). Children in danger coping with the consequences of community vidence. San Francisco, CA: Jossey-Bass Publishers.

Gopie, M. (2003). Psychosocial behavior of adolescent learners from divorced families in Newlands West, Durban: University of Natal. (MED-thesis)

Lochinan, J.E, Lampron, L.B, and Harris, S.R. (1998). Anger coping intervention with aggressive children: A guide to implementation in school settings. In P.A.

Harber, C. 2004. Schooling as violence: how schools harm pupils and societies. London: Routledge.

Harris and Associates, Incoporate,.(1995). Between hope and fear: teens speak out on crime and the community. New York: Author.

Hill, M \& Hill, W. (1994). Creating Safe Schools. What Can Principals Do. California:

Corwin Press.

House of Commons (2007) Select committee on Home Affairs second report Nature and extent of black people's overrepresentation. London: House of Commons.

HM Government (2007) Safe. Sensible. Social. The next steps in the national alcohol strategy. London: The Home Office, The Department of Health, The Department for Education and Skills and The Department for Culture, Media and Sport.

Inman A. G., Howard, E. E., Beaumont, R. L, Waker, J. A. (2007) Cultural Transmission: Influence of Contextual Factors in Asian Indian Immigrant Parents" Experiences: Journal of Counselling Psychology;

Juvenile Justice Bulletin, 2000. Predictors of Youth Violence: USA.

Kopko, K. (2007). Parenting style and adolescents. USA: Cornell University.

Leoschut L, Running Nowhere Fast: Results of the 2008 National Youth Lifestyle Study, Centre for Justice and Crime Prevention, Monograph Series, No. 6, Cape Town, 2009.

Margo, J (2008) Make me a criminal: Preventing youth crime. London: Institute for Public Policy Research.

Matthews, S; Brasnett, L and Smith, J (2006) Underage drinking: Findings from the 2004 Offending, Crime and Justice Survey. London: The Home Office.

McCord, J. and Ensminger, M. (2001) 'Pathways from aggressive childhood to criminality.' Paper presented to the American Society of Criminology, Boston.

$\mathrm{NCH}$ (2008) Step inside our shoes: Young people's views on gun and knife crime. London: NCH. 
Plan. 2008. Learn without fear: the global campaign to end violence in schools. Woking: Plan.

Pinheiro, P. (2006). World report on violence against children. Geneva: United Nations.

Prinsloo, I. J. (2005). How safe are South African Schools? Department of Education

Management and Policy studies. University of Pretoria. South African Journal of

Education Vol 25 (1): 1-5.

Richardson, A and Budd, T (2003) Alcohol, crime and disorder: A study of young adults. London: The Home Office.

SAPS (2007), Crime statistics 2006/2007, SAPS, Pretoria.

South African Institute of Race Relations (2008). South African schools most dangerous in the world. Accessed on 01/03/2010, from http://www.saiir.org.za/press.

Smith, A \& Vaux, T. (2003). Education, conflict and international development. London: DfID.

Steinberg, L. (2001). We know some things: Adolescent-parent relationships in retrospect and prospect. Journal of Research on Adolescence,

Stewart, D. (2004). Learner discipline: An Australian perspective. Koers, 69(2), 317-335.

Thanyani, N.G. (2003). The identification of factors associated with stress among primary school teachers in Soshanguve, Durban: University of Durban-Westville (MED - dissertation).

Turner, K; Hill, M; Stafford, A and Walker, M (2006) "How children from disadvantaged areas keep safe" in Health Education, Vol. 106, No. 6 ,

UN HABITAT (2007), Global report on Human Settlements; crime and violence at glance: UN HABITAT

Utti, Alice (2006) Relationship between Parenting Styles and Students" Academic Achievement in Secondary Schools in Ethiope East L. G. A of Delta State. Unpublished M. Ed Thesis of Delta State University, Abraka.

Utting, D; Montiero, H \& Ghate, D (2006) Interventions for children at risk of developing antisocial personality disorder: Report of the Department of Health and Prime Minister's Strategy Unit. London: Policy Research Bureau.

Ward C. (2007). Young people's violent behaviour: Social learning in context, in Burton P (ed), Someone Stole My Smile: An Exploration into the Causes of Youth Violence in South Africa,CJCP Monograph 3, Cape Town,

Wargo, E. (2007, September). Adolescents and risk: Helping young people make better choices. ACT for Youth Center of Excellence: Research Facts and Findings. Retrieved November 20, 2007, from http://www.actforyouth.net/documents/Adolescent Risk_Sept07.pdf

Young, T; Fitzgerald, M; Hallsworth, S \& Joseph, I (2007) Groups, gangs and weapons. London: Youth Justice Board.

Zulu, BM, Urrbani, G \& Van der Merwe, A. 2004. Violence as an impediment to a culture of teaching and learning in some South African schools. South African Journal of Education 24(2):170-175. 
